\title{
PENGARUH DESAIN KERJA DAN STRES KERJA TERHADAP KUALITAS KERJA GURU SD NEGERI DI KECAMATAN CAKUNG, JAKARTA TIMUR
}

\author{
Yuni Siskawati ${ }^{1}$
}

\begin{abstract}
The purpose of this research is to determine the effect of work design and work stres on work quality in this study teacher elementary school disctric cakung. The research methodology was survey which were selected by simple random sampling technique. Analysis and interpretation of the data indicate that (1) work design has a positive direct effect in work quality, (2) job stres has a negative direct effect in quality work, (3) design work has a negative direct effect in job stress.
\end{abstract}

Keywords: work design, job stress, work quality.

\section{LATAR BELAKANG}

Peningkatan kualitas bangsa Indonesia dalam menghadapi persaingan global yang semakin ketat dilakukan untuk meningkatkan kesejahteraan dan harkat bangsa di mata negara lain, agar mampu berperan dalam persaingan global, pengembangan dan peningkatan kualitas sumber daya manusia perlu terus diupayakan. Peningkatan kualitas sumber daya manusia merupakan kenyataan yang harus dilakukan secara terencana, terarah, intensif, efektif dan efisien dalam proses pembangunan, kalau tidak ingin bangsa ini kalah bersaing dalam menjalani era globalisasi.

Kualitas guru Indonesia disampaikan oleh Wakil Sekretaris Jendral Komisi Nasional Pendidikan, Sukmawardana. Dia mengatakan bahwa saat ini kualitas dan kompetensi guru masih sangat rendah. Bukti dari rendahnya kualitas guru Indonesia antara lain dapat dilihat dari 1) Masih banyaknya guru yang enggan mengembangkan kemampuan diri 2)Tidak berpijak pada program mengajar 3) Tidak menguasai metode pembelajaran yang dapat menumbuhkan minat belajar siswa meningkat 4) Selain itu, pendapatan guru masih sangat kurang.

Pernyataan tersebut di pertengas oleh Kasi SD/PLB Sudin Pendidikan Jakarta Timur bapak Samidi, letak kecamatan cakung yang berada di lingkungan pabrik banyak pengaruh negatif baik bagi murid-murid atau guru nya sendiri, diantaranya akses menuju kesekolah didaerah itu yang sulit di jangkau dengan waktu yang tepat dikarenakan akses menuju kesekolah cukup padat bersamaan dengan hilir mudiknya bus, truk bahkan kointainer perusahaan. Ini mengakibatkan stres yang dapat berdampak menurunnya kualitas kerja guru. Karena sudah lelah terlebih dahulu sebelum guru masuk ke sekolah.

Seperti yang telah diketahui, kualitas kerja di Cakung semakin memburuk. Hal ini terjadi karena efektifitas, efisiensi, dan standardisasi pendidikan yang masih kurang dioptimalkan. Masalah-masalah lainnya yang menjadi penyebabnya adalah rendahnya sarana fisik, rendahnya kualitas guru, rendahnya kesejahteraan guru, rendahnya prestasi siswa, rendahnya kesempatan pemerataan pendidikan, rendahnya relevansi pendidikan dengan kebutuhan, dan mahalnya biaya pendidikan. Sarana pembelajaran juga turut menjadi faktor semakin terpuruknya pendidikan di Indonesia, terutama bagi penduduk di daerah terbelakang. Namun, bagi penduduk di daerah terbelakang

\footnotetext{
${ }^{1}$ Guru SD Negeri di Kecamatan Cakung.
} 
tersebut, yang terpenting adalah ilmu terapan yang benar-benar dipakai untuk hidup dan kerja.

Kualitas kepemimpinan kepala sekolah dan pengawas menjadi focus untuk menguatkan para aktor pendidikan di sekolah. Hal itu berguna menciptakan ekosistem sekolah yang baik. Program-program pendidikan dan pelatihan bukan lagi diisi dengan urusan administratif, melainkan subsatansinya untuk memberdayakan kepala sekolah agar dapat meningkatkan kualitas kerja guru. Di pertegas kembali oleh Kepala sudin Pendidikan Wilayah 1 Kota Administrasi Jakarta TImur, Ari Budiman, "pendidikan itu salah satu faktor yang sangat penting didalam sebuah kemajuan atas kemunduran suatu wilayah. Wilayah Jakarta Timur merupakan salah satu bagian dari provinsi DKI Jakarta yang memiliki letak yang sangat strategis dan terluas dengan luas $188 \mathrm{Km}^{2}$ dengan jumlah penduduk 2.693.896 Jiwa dengan tingkat kepadatan 14.327/ $\mathrm{Km}^{2}$. dan memiliki daerah industri terbesar terutama di kecamatan cakung yang identik dengan wilayah pabrik, oleh karena itu perlu adanya perhatian yang lebih kepada guru-guru yang bekerja di daerah tersebut

Faktor yang paling dominan bagi pencapaian kualitas pendidikan adalah penerapan model manajemen sekolah yang sesuai dengan kultur dan budaya sekitarnya. Kualitas produk pendidikan dapat tercapai, dengan adanya tenaga kependidikan yang berkualitas pula. Dalam pendidikan guru merupakan faktor yang sangat vital, karena guru merupakan ujung tombak dalam pembelajaran. Sesuai dengan pendapat salah satu pengawas TK/SD di kecamatan cakung bapak Djuchana, guruguru di sekolah wilayah kecamatan cakung memiliki stress kerja yang cukup tinggi salah satunya faktor transportasi yang di hadapi yang dihadapkan dengan rutinitas kemacetan dan masih perlunya peningkatan sumber daya manusia diantaranya pendalaman mengenai desain kerja. Bagaimana guru dapat mengenal penentuan tugas guru dalam satu semester, penyusunan perencanaan tugas dengan baik, dan bertanggung jawab atas pekerjaannya.

Berdasarkan permasalahan di atas, peneliti ingin mengetahui lebih jelas faktor penyebab rendahnya kualitas kerja guru, melalui penelitian yang berjudul "Pengaruh desain kerja dan stres kerja terhadap kualitas kerja guru di SD Negeri kecamatan Cakung Jakarta Timur

\section{Kualitas Kerja}

Juran memperkenalkan konsep "Trilogy" kualitas dan mengidentifikasikannya dalam tiga kegiatan yaitu perencanaan kualitas, pengendalian kualitas, dan peningkatan kualitas. Menurut Juran (2012:41), "believed that quality does not just happen, it has to be planned". Kualitas tidak berjalan begitu saja tetapi harus direncanakan. Dalam perencanaan kualitas, suatu kualitas seharusnya direncanakan atau dirancang, yang terdiri atas tahap-tahap sebagai berikut meliputi: menetapkan siapa pelanggan, menetapkan kebutuhan pelanggan, mengembangkan keistimewaan produk merespon kebutuhan pelanggan, mengembangkan proses yang mampu menghasilkan keistimewaan produk, mengarahkan perencanaan menuju kegiatan-kegiatan operasional.

Menurut John M.Ivancevich (2010:26), "quality is defined as meeting costumersneeds and expectation". Kualitas didefinisikan sebagai pertemuan antara kebutuhan dan harapan konsumen. Selanjutnya Stephen P. Robbins, Mary Coulter (2014:346) mengemukakan, "quality as the ability of a product or service to reliable do what it's supposed to do and to satisfy customer expectations". Kualitas sebagai kemampuan suatu produk atau 
jasa untuk diandalkan melakukan apa yang seharusnya dilakukan dan untuk memenuhi harapan pelanggan. Menurut Chuck Williams (2011:695), "quality a product or service free of deficiencies or the characteristic of a product or service that satisfy customer needs". kualitas produk atau layanan gratis dari kekurangan atau karakteristik produk atau jasa yang memenuhi kebutuhan pelanggan.

Menurut Samuel C. Certo, S. Trevis Certo (2014:479), "quality is defined as how well a product does what it is supposed to do how closely and reliably it satisfies the specifications to which it is built". Kualitas didefinisikan sebagai seberapa baik produk melakukan apa yang seharusnya dilakukan seberapa dekat dan andal itu memenuhi spesifikasi yang dibangun.

Sejalan dengan pendapat di atas, David L. Goetsch, Stanley B. Davis (2010:5) menyatakan, pengertian kualitas dalam konteks sederhana yaitu, "quality is a dynamic state associated with products, services, people, processes, and environments that meets or exceeds expectations". Kualitas adalah kondisi dinamik yang berhubungan dengan produk, jasa, manusia, proses, dan lingkungan yang memenuhi atau melebihi harapan. Maknanya bahwa kualitas menunjukkan kelebihan dalam hal layanan individu atau institusi dan produk yang dihasilkan untuk orang lain.

Berdasarkan uraian mengenai kualitas kerja di atas, dapat disintesiskan bahwa kualitas kerja adalah kesesuaian pemberi layanan terhadap pelanggan untuk membantu dan memenuhi kebutuhan dalam menyelesaikan masalah-masalah pelanggan dalam rangka pencapaian tujuan yang meliputi indikator: (1) fokus pada pelanggan, (2) kehandalan, dan (3) memenuhi harapan pelanggan.

\section{Desain Kerja}

Desain kerja adalah proses penentuan tugas-tugas yang akan dilaksanakan, metode-metode yang digunakan untuk melaksanakan tugas ini, dan bagaimana pekerjaan tersebut berkaitan dengan pekerjaan lainnya di dalam perusahaan. Desain pekerjaan mutlak dimiliki oleh setiap lembaga karena dalam desain pekerjaan yang dilakukan adalah merakit sejumlah tugas menjadi sebuah pekerjaan yang dilakukan menjadi terarah dan jelas. Pendapat Jennifer M. George, Gareth R. Jones (2012:183), "job design is the process of linking specific tasks to specific jobs and deciding what techniques, equipment and procedures should be used to perform those task". Desain pekerjaan adalah proses menghubungkan tugas-tugas tertentu untuk pekerjaan tertentu dan memutuskan apa teknik, peralatan dan prosedur harus digunakan untuk melakukan tugas mereka.

Selanjutnya Steven L. McShane, Mary Ann Von Glinow (2008:176), "job design the process of assigning tasks to a job, including the interdependence of those tasks with other jobs". Desain pekerjaan adalah proses tugas menugaskan ke pekerjaan, termasuk saling ketergantungan tugas-tugas dengan pekerjaan lain. Pendapat senada diungkapkan oleh Ricky W. Griffin, Greogory Moorhead (2014:126), "job design is how organizations define and structure jobs".Desain pekerjaan adalah bagaimana organisasi mendefinisikan dan pekerjaan struktur. Pendapat mengenai desain kerja dikemukakan Fred Luthans (2011:178), "job design may be defined as the methods that management uses to develop the content of a job, including all relevant task, as well as the processes by which jobs are constructed and revised". Desain kerja didefinisikan sebagai metode-metode yang digunakan manajemen untuk mengembangkan muatan kerja, termasuk semua tugas yang relevan, serta proses pekerjaan yang dibangun dan direvisi. 
John R. Schermerhorn, Richard N. Osborn, Mary Uhl-Bein, James G. Hunt (2012:131)mengatakan bahwa desain pekerjaan, "job design is the process through which managers plan and specify jobs tasks and the work arrangements that allow them to be accomplished". Desain pekerjaan adalah proses di mana manajer merencanakan dan menentukan tugas-tugas pekerjaan dan pengaturan kerja yang memungkinkan mereka untuk dicapai.

Berdasarkan deskripsi konsep yang dikemukakan di atas, maka dapat disintesiskan desain pekerjaan adalah proses strukturisasi kerja dengan menentukan, mengatur serta mengembangkan pekerjaan untuk mencapai tujuan organisasi dengan indikator (1) variasi keterampilan, (2) kombinasi tugas, (3) identitas tugas, (4) kemandirian (5) hubungan kerja, (6) pembebanan kerja.

\section{Stres Kerja}

Stres biasanya dianggap sebagai istilah yang buruk (distress), tetapi ada juga sisi stress positif (eustress) yang menyenangkan yang disebabkan oleh hal yang baik. Stres dapat dipandang dengan cara yang berbeda yang bersifat emosional yang digunakan untuk mengacu pada sesuatu yang membutuhkan penjelasan. Sementara itu pendapat John W. Slocum (2009:188-189) mengatakan bahwa, "job stress is a common and costly problem in the workplace, leaving few workers untouched. Stress is the excitement, feeling of anxiety, and/or physical tension that occurs when the demands placed on an individual are though to exceed the person's ability to copet". Dari pendapat tersebut dapat didefinisikan bahwa stres kerja adalah masalah umum yang sering terjadi di tempat kerja, dengan meninggalkan beberapa pekerjaan yang tak terselesaikan. Sedangkan definisi stres adalah perasaan gembira, kecemasan, dan ketegangan fisik yang terjadi ketika tuntutan individu diperkirakan melampaui kemampuan seseorang. Hal ini merupakan pandangan yang paling umum dari stres dan sering disebut tekanan atau stres negatif. Banyak faktor yang membuat karyawan mengalami stres kerja, termasuk persepsi mereka tentang situasi, pengalaman masa lalu, kehadiran atau tidak adanya dukungan sosial, dan berbagai perbedaan individu.

John Bernardin (2007:13) mengatakan, "job stress has been defined as a situation wherein job related factors interact with a worker to change his or her psychological and/or psychological condition such that the person is forced to deviate from normal functioning. Stress is considered to be a major problem for workers in todays turbulent and highly competitive environment, with its emphasis on cost control, reduced labor expense amd higher productivity". Berdasarkan pendapat di atas dapat dikatakan bahwa stres kerja didefinisikan sebagai situasi dimana faktor-faktor pekerjaan berhubungan dan berinteraksi dengan pekerja untuk mengubah kondisi psikologinya sehingga orang tersebut dipaksa untuk menyimpang dari fungsi normal. Stres dianggap menjadi masalah besar bagi lingkungan pekerja dan sangat kompetitif, dengan penekanan dan pengendalian biaya, biaya operasional berkurang dengan produktivitas yang lebih tinggi.

Berdasarkan pembahasan di atas dapat disintesiskan bahwa stres kerja adalah situasi ketegangan, tekanan emosional yang dialami seseorang yang dapat mempengaruhi emosi, pikiran dan kondisi fisik seseorang. Indikator dari stres kerja adalah gejala fisiologis, gejala psikologis, dan tindakan individu.

\section{METODE PENELITIAN}


Penelitian ini menggunakan metode survey dengan teknik analisis jalur (path analys) Data penelitian ini dikumpulkan dengan cara memilih sampel dalam populasi. Populasi terjangkau dalam penelitian ini adalah seluruh guru SD Negeri di Kecamatan Cakung yang berjumlah 219 guru. Dan perhitungan dengan menggunakan slovin, maka di peroleh jumlah sampel sebanyak 142 guru yang dijadikan sampel frame dalam penelitian ini. Data yang dikumpulkan dalam penelitian dijaring melalui kuesioner yang berupa skala penilaian (rating scale) dengan sebaran skor antara 1 sampai dengan 5. Selanjutnya dilakukan uji coba intrumen untuk menentukan butir-butir instrumen yang valid dan reliabel. Teknik analisis data dilakukan dengan statistika deskriptif dan statistika inferensial dengan terlebih dahulu melakukan uji prasyarat analisis yaitu normalitas populasi dan analisis regresi.

\section{HASIL PENELITIAN DAN PEMBAHASAN \\ Pengaruh Desain kerja terhadap Kualitas Kerja.}

Berdasarkan hasil perhitungan koefisien korelasi 0.343 dan nilai koefisien jalur sebesar 0.284. hal ini bermakna bahwa desain kerja berpengaruh secara langsung terhadap kualitas kerja.

Hasil penelitian ini senada dengan pendapat beberapa ahli di antaranya adalah berdasarkan kajian teoretik dan hasil sintesis yang dikemukakan sebelumnya, diketahui bahwa desain kerja adalah penetapan pekerjaan seseorang atau sekelompok pegawai secara organisasional dengan tujuan untuk mengatur penugasan kerja agar dapat memenuhi kebutuhan organisasi yang mempengaruhi kualitas kerja dalam melaksanakan tugas-tugasnya.

Dalam manajemen sumberdaya manusia, salah satu cara mengoptimalkan kinerja pegawai dengan adanya kesesuaian penerapan karakteristik pekerjaan atau desain kerja yang mencakup diantaranya variasi tugas, uraian keterampilan, kepentingan tugas, wewenang dan umpan balik. Pendekatan klasik mengenai desain pekerjaan dikemukakan Hackman dan Oldham dalam Luthans dengan teori karakteristik pekerjaan (job characteristics theory)

Tingkat stres tinggi disertai dengan kemarahan, kecemasan, depresi, gelisah, cepat marah, tegang dan bosan. Sebuah studi menemukan bahwa dampak stres yang paling kuat adalah tindakan agresif seperti sabotase, agresi antar pribadi, permusuhan dan keluhan. Jenis masalah psikologis tersebut relevan dengan kualitas yang buruk, penghargaan diri yang rendah, benci pada pengawasan, ketidakmampuan untuk berkosentrasi dan membuat keputusan. Samuel C. Certo, S. Trevis Certo (2014:479) menjelaskan, "quality is defined as how well a product does what it is supposed to do how closely and reliably it satisfies the specifications to which it is built". Kualitas didefinisikan sebagai seberapa baik produk melakukan apa yang seharusnya dilakukan seberapa dekat dan andal itu memenuhi spesifikasi yang dibangun. Sejalan dengan pendapat di atas, David L. Goetsch, Stanley B. Davis (2010:5) menyatakan, pengertian kualitas, yaitu, "quality is a dynamic state associated with products, services, people, processes, and environments that meets or exceeds expectations". Kualitas adalah kondisi dinamik yang berhubungan dengan produk, jasa, manusia, proses, dan lingkungan yang memenuhi atau melebihi harapan. Dengan demikian, ketepatan dalam disain kerja dapat mengakibatkan peningkatan kualitas kerja seseorang.

\section{Pengaruh Stres Kerja terhadap Kualitas Kerja}


Dari hasil pengujian hipotesis kedua dapat disimpukan bahwa terdapat pengaruh langsung negatif stres kerja terhadap kualitas kerja dengan nilai koefisien korelasi sebesar -0,294 dan nilai koefisien jalur sebesar -0,216. Ini memberikan makna stres kerja berpengaruh langsung terhadap kualitas kerja.

Hasil penelitian ini senada dengan pendapat beberapa ahli di antaranya adalah Lazarus, R.S and S. Folkman (2015:132) mengatakan stres kerja dapat berdampak kepada kualitas kerja, "stress is defined as a psychological response to demand that possess certain stakes for the person and that tax or exceed the person's capacity or resources. the demands that cause people to experience stress are called stressors. the negative consequences that occur when demands tax or exceed a person's capacity or resources are called strains. this definition of stress illustrates that it depends on both the nature of the demand and the person who confronts it. people differ in terms of how they perceive and evaluate stressors and the way they cope with them. as a result, different people may experience different levels of stress even when confronted with the exact same situation". Stres didefinisikan sebagai respon psikologis permintaan yang memiliki saham tertentu untuk orang dan pajak yang melebihi kapasitas atau atau sumber daya seseorang. tuntutan yang menyebabkan orang mengalami stres disebut stressor. konsekuensi negatif yang terjadi ketika pajak tuntutan atau melebihi kapasitas atau sumber daya seseorang disebut strain. definisi stres menggambarkan bahwa itu tergantung pada kedua sifat permintaan dan orang yang berhadapan dengannya. orang berbeda dalam hal bagaimana mereka memahami dan mengevaluasi stres dan cara mereka mengatasi dengan mereka. sebagai akibatnya, orang yang berbeda mungkin mengalami berbagai tingkat stres bahkan ketika dihadapkan dengan situasi yang sama persis.

Selanjutnya Schermerhorn (2012:37), menyatakan, "stress as state of tendention experienced by individuas facing extraordinary demand, constraints, or opportunity. As we show, stress can be both positive and negative and is important fact of live in our present work Environment". Stres seperti yang dialami oleh individu cenderung untuk menghadapi permintaan yang luar biasa, kendala, atau kesempatan. Seperti telah ditunjukkan, stres bisa positif dan negatif dan merupakan fakta penting dalam kehidupan di lingkungan kerja kita saat ini.

Menurut Bernardin (2007:379) mengemukakan, "stress is making workers sick, increasing the potential for violence at work, and affecting productivity and accident rates". Stres adalah membuat pekerja sakit, meningkatkan potensi terhadap kekerasan di tempat kerja, dan mempengaruhi tingkat produktivitas dan kecelakaan dalam bekerja dan akan mempengaruhi kualitas kerja seseorang. Selanjutnya menurut John R. Schemerhorn, JR, Richard N. Osborn, Mary Uhl-Bein, James G hunt (2012:36) mengatakan bahwa stres kerja akan berdampak kepada kualitas pekerjaan seseorang, "life stressors. a less obvious, though important, source of stress for people at work is the spill lover effect that result when forces in their personal lives spill over to affect them at work. such life stressors as family event, economic difficulties and personal affairs can be all be extremely stressful. since it is often difficult to completely separate work and non work lives, life stressors can affect the way people feel and behave on their job as well in their personal lives". Tekanan hidup. Stres bagi orang-orang di tempat kerja adalah efek ketika seseorang meluapkan perasaan dalam kehidupan pribadi mereka melebih batas untuk mempengaruhi mereka di tempat kerja. seperti stres dalam kehidupan sebagai acara keluarga, kesulitan ekonomi dan urusan pribadi dapat semua menjadi sangat menegangkan. Karena seringkali sulit untuk bekerja dengan benar dan memisahkan antara pekerjaan dengan kehidupan non pekerjaan, tekanan hidup dapat mempengaruhi perasaan dan berperilaku pada pekerjaan dan 
dalam melaksanakan kehidupan pribadi mereka yang akan berdampak pada kualitas pekerjaan setiap manusia.

John W. Slocum (2009:188-189) mengatakan bahwa, "job stress is a common and costly problem in the workplace, leaving few workers untouched. Stress is the excitement, feeling of anxiety, and/or physical tension that occurs when the demands placed on an individual are though to exceed the person's ability to copet". Stres kerja adalah masalah umum yang sering terjadi di tempat kerja, dengan meninggalkan beberapa pekerjaan yang tak terselesaikan. Sedangkan definisi stres adalah perasaan gembira, kecemasan, dan ketegangan fisik yang terjadi ketika tuntutan individu diperkirakan melampaui kemampuan seseorang. John Bernardin (2007:13) mengatakan, “job stress has been defined as a situation wherein job related factors interact with a worker to change his or her psychological and/or psychological condition such that the person is forced to deviate from normal functioning. Stress is considered to be a major problem for workers in todays turbulent and highly competitive environment, with its emphasis on cost control, reduced labor expense amd higher productivity". Stres kerja didefinisikan sebagai situasi di mana faktor-faktor pekerjaan berhubungan dan berinteraksi dengan pekerja untuk mengubah kondisi psikologinya sehingga orang tersebut dipaksa untuk menyimpang dari fungsi normal. Stres dianggap menjadi masalah besar bagi lingkungan pekerja dan sangat kompetitif, dengan penekanan dan pengendalian biaya, biaya operasional berkurang dengan produktivitas yang lebih tinggi. Stephen P. Robbins, Mary Coulter (2014:346) mengemukakan, "quality as the ability of a product or service to reliable do what it's supposed to do and to satisfy customer expectations". Kualitas sebagai kemampuan suatu produk atau jasa untuk diandalkan melakukan apa yang seharusnya dilakukan dan untuk memenuhi harapan pelanggan. Menurut Chuck Williams (2011:695), "quality a product or service free of deficiencies or the characteristic of a product or service that satisfy customer needs". kualitas produk atau layanan gratis dari kekurangan atau karakteristik produk atau jasa yang memenuhi kebutuhan pelanggan. Dengan demikian, peningkatan stres dapat mengakibatkan penurunan kualitas kerja seseorang.

\section{Pengaruh Desain Kerja terhadap Stres Kerja}

Dari hasil pengujian hipotesis ketiga dapat disimpulkan bahwa terdapat pengaruh langsung negatif Desain kerja terhadap stres kerja dengan nilai koefisien korelasi sebesar $-0,275$ dan nilai koefisien jalur sebesar -0,275. Ini memberikan makna desain kerja berpengaruh langsung terhadap stress kerja.

Hasil penelitian ini senada dengan pendapat beberapa ahli di antaranya adalah Don Hellriegel dan John W. Slocum (2004:184) sebagai berikut, "organizational initiatives for managing stress are typically designed to reduce the harmful effects of stress in three ways: (1) identify and then modify eliminate work stressors, (2) help employees modify their perception and understanding of work stress, and (3) help employees cope more effectively with the consequences of stres". Inisiatif organisasi untuk mengelola stres biasanya dirancang untuk mengurangi efek berbahaya dari stres dalam tiga cara: (1) mengidentifikasi dan kemudian memodifikasi menghilangkan stres kerja, (2) membantu karyawan mengubah persepsi dan pemahaman tentang stres kerja, dan (3) membantu karyawan mengatasi lebih efektif dengan konsekuensi stres. Vijay V. Raghavan (2014) menyatakan sebagai berikut, "this study explores whether organizations can employ job design strategies to relieve organizational stress for information technology IT professionals. The effect of flexible work schedule, employee support and training, and telecommuting as potential coping resources to relieve stress were studied. Perceived workload, role ambiguity, work facilitation, and decision 
latitude were drawn from previous studies as potential stressors of IT professionals. Perceived stress was measured by two commonly used measures: work exhaustion and depressed mood. The results suggest that removing role ambiguity and improving work-facilitation ease work-related stress. Allowing employees to have flexible work schedules was also found to ease their perceptions of workload. Employee support and training strategies were found to influence decision latitude and role ambiguity. Telecommuting did not have any effect on the stressors. Results also indicate that the association between work exhaustion and depressed mood was stronger for males than females". Penelitian ini mengeksplorasi apakah organisasi dapat menggunakan strategi desain pekerjaan untuk menghilangkan stres organisasi untuk teknologi informasi profesional TI. Pengaruh jadwal yang fleksibel kerja, dukungan karyawan dan pelatihan, dan telecommuting sebagai sumber daya potensial mengatasi untuk meringankan stres dipelajari. Persepsi beban kerja, peran ambiguitas, fasilitasi kerja, dan keputusan lintang diambil dari studi sebelumnya sebagai stres potensial profesional TI. Dirasakan stres diukur dengan dua ukuran yang umum digunakan: kelelahan kerja dan perasaan depresi. Hasil menunjukkan bahwa menghapus ambiguitas peran dan meningkatkan stres yang berhubungan dengan pekerjaan kerja fasilitasi kemudahan. Memungkinkan karyawan untuk memiliki jadwal kerja yang fleksibel juga ditemukan untuk meringankan persepsi mereka tentang beban kerja. Strategi dukungan karyawan dan pelatihan yang ditemukan untuk mempengaruhi keputusan lintang dan ambiguitas peran. Telecommuting tidak memiliki efek pada stres. Hasil penelitian juga menunjukkan bahwa hubungan antara kelelahan kerja dan perasaan depresi lebih kuat untuk laki-laki daripada perempuan.

Jennifer M. George, Gareth R. Jones (2012:183) menjelaskan, "job design is the process of linking specific tasks to specific jobs and deciding what techniques, equipment and procedures should be used to perform those task". Desain pekerjaan adalah proses menghubungkan tugas-tugas tertentu untuk pekerjaan tertentu dan memutuskan apa teknik, peralatan dan prosedur harus digunakan untuk melakukan tugas mereka. Selanjutnya Steven L. McShane, Mary Ann Von Glinow (2008:176) mendeskripsikan, "job design the process of assigning tasks to a job, including the interdependence of those tasks with other jobs". Desain pekerjaan adalah proses tugas menugaskan ke pekerjaan, termasuk saling ketergantungan tugas-tugas dengan pekerjaan lain. Bernardin (2007:379) mengemukakan, "stress is making workers sick, increasing the potential for violence at work, and affecting productivity and accident rates". Stres membuat pekerja sakit, meningkatkan potensi terhadap kekerasan di tempat kerja, dan mempengaruhi tingkat produktivitas dan kecelakaan dalam bekerja dan akan mempengaruhi kualitas kerja seseorang. Dengan demikian, kete[patan dalam disain kerja akan mengakibatkan penurunan stres dalam bekerja.

\section{DAFTAR RUJUKAN}

Bernardin, John, Human Resource Management an experiental Approach. New York: McGraw-Hill, 2007.

Bisen, Vikram, Priya, industrial psychology New Delhi: New age internastional Ltd, 2010. 
Campbell, James quick, jonathan D. Quick, debra L. Nelson, Joseps J. Hurrell, preventive stress management in organizations. Washington, DC: American psychological association, 1997.

Certo, Samuel C., S. Trevis Certo, Modern Management concept and skills 13 edition. USA: Pearson, 2014.

Colquitt, Jason A., Jeffery A. Lepine, Michael J. Wesson, Organizational behavior improving performance and commitment in the workplace 4 edition (New York: McGraw-Hill, 2015.

Dessler, Gary, Human Resource Management. Pearson Education: Prentice Hall., 2011.

George, Jenniffer M. R. Jones, Understanding and Managing Organizational Behavior Sixth Edition. New Jersey: Pearson, 2012.

Goetsch, David L., Stanley B. Davis, Quality Management, 6 dition. New Jersey:Prentice Hall, 2010.

Griffin, Ricky W., Greogory Moorhead, Organizational Behavior Managing People and Organization Eleventh Edition. United State: South Western Cengage Learning, 2014.

Ivancevich John M., Organizational Behaviour and Management. New York: McGraw-Hill, 2010.

John M. Ivancevich, Organizational Behaviour and Management (New York: McGraw-Hill, 2010.

Kinicki, Robert Williams, Management a Practical Introduction, New York: McGraw-Hill Companies Inc, 2011.

Luthans . Fred, Jonathan P. Doh, International Management. Singapore: McGraw-Hill International, 2009.

Luthans, Fred: Organizational Behavior, 12 ${ }^{\text {th }}$ Edition. Singapore: McGraw Hill International, 2011.

McShaen, Steven L., Mary Ann Von Glinow, Organizational Behavior 4 th Edition. New York: Mc Graw Hill, 2008.

Nanda, Vivek, Quality Management System Handbook for Product Development Companies. Washington DC: CRC Press, 2005.

Robbins, Stephen P., Mary Coulter, Management 12 edition. USA: Pearson Educational Inc, 2014.

Sallis, Edwar, Total Quality Management in Education. Jogjakarta: IRCiSod, 2012. 
Schermerhon John R., Management. USA: Jhon Wiley and Sons Inc, 2011.

Schermerhorn, John R., Richard N. Osborn, Mary Uhl-Bein, James G. Hunt, Organizational Behavior 12 Edition. Asia: Wiley, 2012.

Slocum, Hellriegel, Principle of Organizational Behavior. Arizona: South Western, 2009. 
